NBER WORKING PAPER SERIES

\title{
A RETROSPECTIVE LOOK AT RESCUING AND RESTRUCTURING GENERAL MOTORS AND CHRYSLER
}

\author{
Austan D. Goolsbee \\ Alan B. Krueger \\ Working Paper 21000 \\ http://www.nber.org/papers/w21000
NATIONAL BUREAU OF ECONOMIC RESEARCH
1050 Massachusetts Avenue
Cambridge, MA 02138
March 2015

The authors are grateful to Anthony Casey, Steve Rattner, Harry Wilson, Tim Taylor, David Autor and Chang-Tai Hsieh for helpful comments, and to David Cho and Loullya Saney for excellent research assistance. This paper was prepared for the Journal of Economic Perspectives. Austan Goolsbee wishes to thank the University of Chicago Booth School of Business's Initiative on Global Markets for financial support. The views expressed herein are those of the authors and do not necessarily reflect the views of the National Bureau of Economic Research.

NBER working papers are circulated for discussion and comment purposes. They have not been peerreviewed or been subject to the review by the NBER Board of Directors that accompanies official NBER publications.

(C) 2015 by Austan D. Goolsbee and Alan B. Krueger. All rights reserved. Short sections of text, not to exceed two paragraphs, may be quoted without explicit permission provided that full credit, including (C) notice, is given to the source. 
A Retrospective Look at Rescuing and Restructuring General Motors and Chrysler Austan D. Goolsbee and Alan B. Krueger

NBER Working Paper No. 21000

March 2015

JEL No. E0,G01,G33,H0,J01,L50,L62

\title{
ABSTRACT
}

This paper takes a retrospective look at the U.S. government's effort to rescue and restructure General Motors and Chrysler in the midst of the 2009 economic and financial crisis. The paper describes how two of the largest industrial companies in the world came to seek a bailout from the U.S. government, the analysis used to evaluate their request, and the steps taken by the government to rescue them. The paper also summarizes the performance of the U.S. auto industry since the bailout and draws some general lessons from the episode.

\author{
Austan D. Goolsbee \\ Booth School of Business \\ University of Chicago \\ 5807 S. Woodlawn Avenue \\ Chicago, IL 60637 \\ and NBER \\ goolsbee@chicagobooth.edu \\ Alan B. Krueger \\ Industrial Relations Section \\ Firestone Library, Room A2H \\ Princeton University \\ Princeton, NJ 08544 \\ and NBER \\ akrueger@princeton.edu
}


The rescue of the U.S. automobile industry amid the 2008-2009 recession and financial crisis was a consequential, controversial, and difficult decision made at a fraught moment for the U.S. economy. Both of us were involved in the decision process at the time, but since have moved back to academia. As more than five years have passed since the bailout began, it is timely to look back at this unusual episode of economic policymaking to consider what we got right, what we got wrong, and why.

We are pleased and a bit surprised by how well the last five years have played out for the domestic auto industry. At a critical point in the internal debate over the auto industry bailouts in March 2009, Larry Summers, at that time director of the National Economic Council, assembled members of the Obama administration’s economic and autos team around his cramped table in the West Wing of the White House. He held a straw vote on whether the advisors believed Chrysler would survive for five years if a government-supported merger with Fiat went through. A narrow majority, including us, voted no. Five years on, both General Motors and Chrysler have survived, rebounded and, by many metrics, appear healthy.

Economic analysis contributed throughout the process of deciding how to respond to the auto companies’ requests for extraordinary support, and President Obama weighed the economic arguments as well as the political and social realities. We agreed with others in the administration that it was essential to rescue GM to prevent an uncontrolled bankruptcy and the failure of countless suppliers, with potentially systemic effects that could sink the entire auto industry. Our analysis suggested that a failure of the much smaller Chrysler, however, would not have systemic effects for the whole industry and that rescuing the company would make it more difficult and more costly for taxpayers to rescue GM, although we recognized that a failure of Chrysler would cause considerable hardship to its workers and their families and communities. 
In the end, the president made the decision to rescue both Chrysler and GM and to put them through a tough restructuring via bankruptcy.

It is hard to argue that this decision did not deliver important economic benefits to the recovery and country, although the government did not recover the full amount of TARP funds it invested. If Chrysler and GM had been allowed to fail, in all likelihood the Great Recession would have been deeper and longer, and the recovery that began in mid-2009 would have been weaker. The rescue has been more successful than almost anyone predicted at the time. Some of this improvement resulted from actions the auto companies took; some happened because consumer demand for autos has been especially strong during the last five years. The auto industry has turned out to be one of the drivers of the economic recovery. Yet we suspect that the conditions that led the auto bailout to be a success were fairly unique in American economic history, and, we hope, unlikely to be repeated anytime soon.

In this article we describe the events that brought two of the largest industrial companies in the world to seek a bailout from the U.S. government, the analysis that was used to evaluate the decision (including what the alternatives were and whether a rescue would even work), the steps that were taken to rescue and restructure Chrysler and GM, and the performance of the U.S. auto industry since the bailout. We close with some of the general lessons to be learned from the episode.

\section{How the U.S. Auto Industry Imploded}

In the run-up to the 2009 bailout, the Big Three automakers recorded some of the worst corporate performances in American history. General Motors alone lost almost $\$ 40$ billion in 2007 and another $\$ 31$ billion in 2008. Ford lost $\$ 3$ billion and then $\$ 15$ billion. Chrysler was a 
privately held company that did not disclose earnings publicly, but was losing comparable amounts of money. When the Great Recession began in late 2007, it had a catastrophic impact on the automakers. Auto sales plummeted in 2008 and again in 2009 to below 10 million, from a peak of mover than 17 million just a few years earlier.

By fall 2008, the financial situation of the domestic auto-makers was so dire that they would soon be unable to make their wage and supplier payments. In November 2008, the CEOs of Ford, General Motors, and Chrysler came before the House and the Senate to request a \$25 billion working capital "bridge loan" from the U.S. government to enable them to make these payments and to help keep them out of bankruptcy and avoid possible liquidation. In the auto executives' view, the crisis they were facing centered on macroeconomic forces outside of their control. Chrysler CEO Robert Nardelli (2008) explained at the outset of the hearing, "We are asking for assistance for one reason: To address the devastating automotive industry recession caused by our Nation's financial meltdown." He said that buyers' and dealers' lack of access to credit was preventing them from buying vehicles and wrecking their business. They were asking for capital to tide them over, with no conditions attached, until conditions returned to normal so that they could avoid bankruptcy or liquidation.

But of course, no one knew if the 17 million annual sales rates achieved earlier in the 2000s would ever return. Auto credit had been unsustainably inflated by the same housing and credit bubble that led to the economic crisis in 2008. The ratio of cars-to-population and the fraction of auto buyers stretching their credit by using subprime auto loans were both at record highs. If demand rebounded only partway toward its previous high after the recession ended, it was not clear that all of the "Big Three" automakers could survive. 
When critics highlighted the U.S. auto industry's decades-old problems of high cost, questionable quality, and the like, the executives argued that they had already done the restructuring necessary to fix those problems. In reality, though, the Big Three automakers' problems had built up over many years, and were certainly not solely a result of the economic downturn.

Falling demand was a persistent and severe problem for the Big Three. Market share trends weighed heavily against them. Figure 1 plots the U.S. market share of each of the Big Three automakers in the decades running up to the crisis, as a percentage of total auto sales. There was a sustained and substantial downward trend in demand of more than 2 percentage points per year for the Big Three combined. The Big Three’s share in 1998 was 71 percent; by 2008, it was 47 percent. These negative trends were especially severe for GM, the largest of the domestic companies.

Figure 2: "Big Three" Automakers' Shares of U.S. Total Vehicle Sales

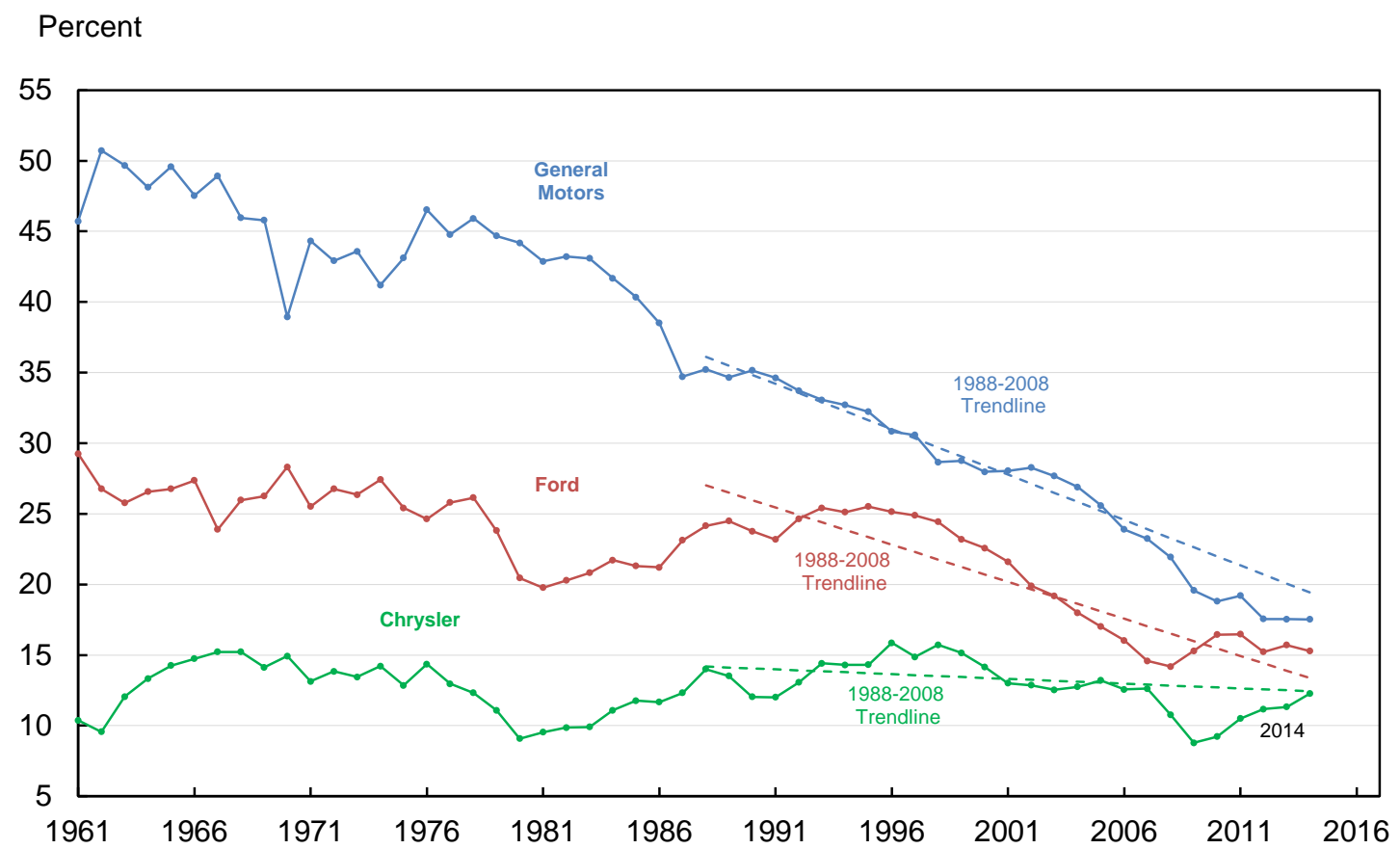


If anything, these declines in market share understate the severity of the dwindling demand facing the manufacturers. The Big Three had been engaged in substantial price discounting relative to the competition. By 2008, the Big Three were discounting comparable cars by $\$ 2,000$ to $\$ 3,000$ (Helper 2010). A number of factors had taken a toll on the demand for cars from the Big Three manufacturers over time: the widespread perception of perennial quality and reliability issues, lower resale values, poorly received new models, and a lack of low-gasmileage cars at times of rising fuel costs.

Moreover, the "transplant” car factories - that is, domestic U.S. production of foreign owned companies like Honda, Toyota, Nissan, and others - were expanding employment and production in the U.S. using predominantly non-union plants in the American South, even as the Big Three automakers had struggled. For example, from 2000 to 2013, employment at the domestic transplant car-makers almost doubled to 163,000, while Big Three employment fell steadily and was cut nearly in half to 253,000 , according to Automotive News data reported in Kurylko (2013). This pattern suggested that the problems of the Big Three legacy U.S. automakers were perhaps particular to those firms, not to the national automobile manufacturing industry.

A common refrain among industry analysts and critics in Congress, was that U.S. automakers were uncompetitive versus their foreign counterparts as well as against the transplant factories. Estimates of the hourly compensation of the Big Three automakers put hourly compensation almost 25 percent higher than in the transplants (Leonhardt 2008). After including the legacy costs of retirees, average labor costs for the Big Three were almost 45 percent higher. In addition, a surprisingly large share of labor compensation for the Big Three 
automakers was a fixed cost, rather than a variable one. Pension and health care costs for retirees are obvious fixed costs, but the United Automobile Workers (UAW) had also negotiated for workers to be paid 95 percent of their salary when they were on layoff, which in effect turned mostly variable labor compensation into a fixed cost. Under these conditions, it was hard to see how a rescue could make the Big Three more cost competitive with rivals at home and abroad for more than a short time, unless it reduced the fixed costs associated with retirees, the uncompetitive compensation levels for existing workers, and the crushing interest payments owed to bondholders.

To summarize, the problems facing the automakers included long-term falling market share, compounded by a massive short-term drop in aggregate demand, with large fixed costs. This resulted in huge short-term losses. But even if they could reduce their fixed costs and even if the recession ended and aggregate demand returned to normal levels in the short-run, unless they could stop their persistent decline in market share, these automakers would soon be back in trouble.

By December 2008, regardless of what one thought the source of the Big Three's problems were or what should or should not have been done in the preceding years, GM and Chrysler faced an existential threat. Congress could not agree to provide the automakers emergency financing and adjourned for the holidays at the end of 2008, leaving the Big Three scrambling. The Bush administration decided to tap into Troubled Asset Relief Program (TARP) funds authorized under the Emergency Economic Stabilization Act (that had been signed into law on October 3, 2008). It leant GM and Chrysler more than $\$ 20$ billion to keep them afloat into early 2009: $\$ 17.5$ billion went directly to the automakers . The rest went to the financing arms of these firms, the General Motors Acceptance Corporation (GMAC) and Chrysler Financial. Ford 
decided not to take government support. Ford had large losses but had borrowed a significant amount of money in 2006 and begun restructuring before the financial crisis struck, so the company was able to withstand the cash crunch.

GM and Chrysler received these loans with the condition that they use the funds to make themselves "viable" as ongoing enterprises. The firms were given until February 2009 to come up with the plans. The new administration took office in late January.

The viability plans that the companies submitted in February 2009 were summarily rejected by the new administration as unrealistic and inadequate, which sent the effort back to the drawing board. The gap in time between the granting of the loans in December 2008 and agreement on a workable plan to restructure the companies and make them financial viable meant that the interim $\$ 20$ billion in loans made to keep the companies afloat while they prepared the original viability plans was unlikely ever to be repaid.

A first obvious consideration was whether GM and Chrysler could just enter one of the standard paths for companies in dire financial trouble. For example, one common approach is for the troubled firm to borrow funds using so-called "Debtor-in-Possession" financing. This financing is allowed to be senior (that is, it would be paid first) to all existing company debt. In the meantime, a distressed company can sell off key pieces of the business to acquire cash, perhaps on the way to finding a full buyer in the intermediate term. But in early 2009, these options were merely fantasy. The financial crisis raged. To be sure, there were speculations early in 2009 that perhaps a large Chinese or other national sovereign wealth fund would be willing to buy major portions of the companies but there was, realistically, no chance of these outcomes happening in the requisite timeframe-if it ever would have happened at all. Even if such a buyer had materialized, scrutiny of these kinds of transactions by antitrust authorities, along with 
the Congress and its Committee on Foreign Investment in the United States, would have taken months and faced a high chance of falling through. There was speculation about a merger of GM and Chrysler, but it was unclear that a merger of two failing companies would solve either of their problems.

Later, during the presidential election of 2012, critics of the rescue argued that private lenders should have been allowed to fund the GM and Chrysler restructurings in bankruptcy. In early 2009, however, such funding simply did not exist. At that moment, for better or for worse, it was government money or bust. Without government funds, GM and Chrysler were on a path to disorderly bankruptcy which would, by all accounts, take years to resolve the myriad disputes among thousands of creditors, suppliers, and so on, and likely meant liquidation.

\section{The Costs of Not Rescuing}

What were some of the more likely outcomes if the government had not acted in early 2009 to extend further assistance to GM and Chrysler? As we and others in the Obama administration investigated this question, the answers we heard were not comforting. The companies themselves would lay off their workers immediately. There would be widespread spillovers into supplier industries and auto dealerships, as well as knock-on macroeconomic effects through a reverse multiplier. The Congressional Oversight Panel (2009) called the companies’ possible collapse “a potentially crippling blow to the American economy that Treasury estimated would eliminate nearly 1.1 million jobs.” Other contemporary estimates suggested that the near-term jobs at risk from a disorderly liquidation could reach as high as 2.5 to 3.3 million jobs (Zandi 2008; Cole, et al. 2008; Scott 2008). 
It was easy to question the methodology of some of the more extreme job loss estimates. For example, although we believed that a bankruptcy reorganization of GM and Chrysler under Chapter 11 would have been so disorderly as to be economically wasteful and destructive, presumably some proportion of the assets the firms would have been put to some use. However, we felt confident that a collapse of both companies would have resulted in the immediate loss of at least 500,000 to 1 million jobs. Total job losses from a messy liquidation of Chrylser by itself, in our estimation at the time, would have been in the neighborhood of 300,000 jobs.

Setting aside the costs to the individuals involved, we knew that job losses of this scale would impose sizable costs on various levels of government, through the need for additional spending on safety net, health care, unemployment insurance and other programs, and we sought to quantify some of these costs. In addition, because the company pension funds would probably also be bankrupted, tens of billions of dollars in pension liabilities would be transferred to the Pension Benefit Guaranty Corporation, which was itself already in a precarious financial position. In considering the costs and benefits of a rescue plan for GM and Chrysler, one had to acknowledge that the alternative of just letting the companies proceed into a disorganized bankruptcy would not be "free."

Of course, this is not to say that government should try to keep all large companies alive because their failure would be painful. We certainly had no desire to put the U.S. economy on the path we perceived that Japan had followed in the preceding decades, where stagnation had continued for years as the government propped up zombie firms that were not viable companies. Further, the auto industry is highly capital-intensive compared with other industries, so if one measured jobs saved on a bang-for-the-buck basis, using money to support other industries might have a larger employment impact. Moreover, the public opinion polling reported at the meetings 
with President Obama suggested that large majorities opposed bailouts for any firms, including auto companies.

As the policy team grappled with these issues, a consensus emerged that allowing both companies into uncontrolled bankruptcy was ill-advised. We heard numerous experts opine that a failure of GM, in particular, would level a major blow to consumer confidence that would have an outsized negative impact on spending as well as the argument that this was the equivalent of negative stimulus precisely when the fiscal and monetary policy authorities were attempting to provide positive stimulus. The negative aggregate impact of a disorderly failure of GM would be too great at exactly the wrong moment for the economy. Thus, the question arose of whether we should rescue GM but let Chrysler, the smaller and weaker of the two firms, go into a disorderly bankruptcy.

We had several concerns about the merits of a Chrysler bailout. First, auto sales had plummeted from 16.5 million units in 2006 to 9.5 million in 2009. Our forecasts at the time, and those of many industry analysts, suggested that U.S. auto sales in a steady state would be around 15 to 15.5 million a year. We thought that Chrysler and GM, which had been losing market share for decades, were viable restructured businesses if the market was over 16 million cars, but would there be sufficient demand for both Chrysler and GM to be profitable in the long run? Trying to keep each of the Big Three in operation with such a low rate of sales might endanger them all.

Second, our internal research and reading of the industrial organization literature on demand elasticities in the auto industry indicated that consumers who buy from Chrysler would likely turn to Ford or GM if their preferred Chrysler model was not available. Table 1 illustrates this point with sales data from 2008 by market segment. About 75 percent of Chrysler's sales 
Table 1: Sales by Market Segment

\begin{tabular}{|c|c|c|c|}
\hline Segment & Share of Total Chrysler Sales & $\begin{array}{l}\text { Share of } \\
\text { Total Market } \\
\text { Sales }\end{array}$ & $\begin{array}{c}\text { GM+FORD share of Non-Chrysler } \\
\text { Sales }\end{array}$ \\
\hline Full-Size Pickup & 22.2 & 12.3 & 87.4 \\
\hline Minivan & 21.5 & 4.5 & 11.7 \\
\hline Mid-Size SUV & 10.5 & 10.1 & 48.3 \\
\hline Full-Size SUV & 9.6 & 4.8 & 77.6 \\
\hline Full-Size & 8.8 & 5.5 & 83.1 \\
\hline \multirow[t]{2}{*}{ Sports Car } & $\underline{1.9}$ & $\underline{1.8}$ & $\underline{66.7}$ \\
\hline & 74.5 & 39 & 65.8 \\
\hline Compact & 12.3 & 18.8 & 30.3 \\
\hline Mid-Size & 7.1 & 16.4 & 23.2 \\
\hline Compact SUV & 3.3 & 7.9 & 42 \\
\hline \multirow[t]{2}{*}{ Mid-Size Pickup } & $\underline{2.4}$ & $\underline{2.5}$ & $\underline{22.3}$ \\
\hline & 25.1 & 45.6 & 29.3 \\
\hline Entry Luxury & 0 & 4.1 & 0 \\
\hline Sub Compact & 0 & 2.9 & 14.7 \\
\hline Mid-Size Luxury SUV & 0 & 2.5 & 13.7 \\
\hline Mid-Size Luxury & 0 & 2 & 34.9 \\
\hline Full-Size Luxury & 0 & 1 & 45.7 \\
\hline Full-Size Luxury SUV & 0 & 1 & 70 \\
\hline Compact Pickup & 0 & 0.5 & 98.1 \\
\hline Sports Car Luxury & 0 & 0.5 & 1.8 \\
\hline MPV & 0 & 0.4 & 0 \\
\hline \multirow[t]{2}{*}{ Compact Luxury SUV } & $\underline{0}$ & $\underline{0.3}$ & $\underline{0}$ \\
\hline & $\mathbf{0}$ & 15.2 & 20.5 \\
\hline TOTAL & 100 & 100 & 41.4 \\
\hline
\end{tabular}

Notes: The model level sales data were compiled by Automotive News and we obtained them from the Good Car Bad Car archives at http://www.goodcarbadcar.net/2013/02/2008-america-auto-sales-rankings-by-model.html and then summed them by the segment definitions in the Wikipedia Car Classification page. 
were concentrated in large cars, minivans, SUVs and trucks. This was almost double the share of sales in those segments in the full passenger vehicle market. Non-Chrysler demand in those segments was heavily domestic: two-thirds of non-Chrysler sales in these Chrysler-heavy segments went to GM or Ford. Even these numbers understate the degree of overlap among the domestic firms by not including minivans and full-size pickup trucks such as the Toyota Sienna, Honda Odyssey, or Toyota Tundra that were not made by the Big Three, but were still domestically produced in the transplant factories. If consumer demand starts with choosing a segment (that is, the kind of car you wish to buy like a minivan or a sports car)) and then a particular model, Chrysler's failure might have a much smaller impact on the economy than people feared. Chrysler's failure might, for example, simply mean that Dodge Ram buyers would, instead, buy another full-sized pickup and all of those models are produced domestically. Nationwide net employment loss from Chrysler's liquidation in this type of situation would be much smaller than the national estimates suggested, as consumers would switch to other domestically produced cars in the absence of Chrysler. And letting Chrysler fail would have substantially reduced the amount of money needed to rescue GM and increased GM and Ford's profitability.

Third, Chrysler had been acquired and restructured twice before without success. The merger between Daimler-Benz and Chrysler that took place in 1998, but was dissolved in 2007, had proved unsuccessful in a more favorable economic environment. The buyout by private equity company Cerberus in 2007 had been unable to stem the problems, and instead added more years of malaise and mismanagement. We saw little prospect that a purchase of Chrysler by Fiat would provide more synergies or a more reassuring brand name for American consumers. Furthermore, automobiles are a business with large economies of scale and Chrysler operated at 
a notably smaller scale than the largest car companies like GM, Toyota, Ford, and others_even with Fiat as a partner.

From a hard-nosed triage view, it was unclear why Chrysler should receive special treatment, especially given that public bailout money could probably save more jobs in a less capital intensive industry and a liquidation of Chrysler did not seem to pose a systemic threat. Even if our fears were accurate that the failure of Chrysler would cause 300,000 workers employed there and in the auto supply chain to lose their jobs (assuming no substitution to other domestic producers in the short run), the U.S. labor market in early 2009 was in miserable shape. Job separations at this time were running at 4 to 5 million per month in the private sector workforce according to data from the Job Opportunities and Labor Turnover Survey (JOLTS), and net job losses at this time (after hiring was taken into account) were running around 700,000 per month. Indiscriminate carnage from the financial crisis existed in virtually every industry. Of course, there were also economic arguments in favor of rescuing Chrysler. First, although we expected that shortfalls in supply caused by the failure of Chrysler could in time be picked up by an expansion of the other auto manufacturers, and that viable segments of Chrysler's business—-such as its minivan unit or Jeep division—would eventually be acquired by other auto companies, “eventually” could take a long time. A messy liquidation of Chrysler would make the transition costs higher.

Another important factor in the decision related to the nature of the auto industry itself, which threatened a kind of negative contagion because of company interdependence. Over the preceding decades, a larger and larger fraction of the value-added in the auto industry had migrated to auto suppliers. Large suppliers of seats, electrical systems and other components normally supplied multiple car companies, and many of the largest auto suppliers such as Lear, 
American Axle, and Visteon were in dire financial shape. Hundreds of suppliers were known to be teetering on the edge (Stoll and McCracken 2009; Kiley 2009; Helper 2010).

The Motor and Equipment Manufacturers Association (2009) submitted data showing that 66 percent of Chrysler suppliers were also suppliers to GM and 54 percent were suppliers to Ford. In previous years, even some seemingly modest supplier disruptions or specific parts shortages resulting from strikes or natural disasters had caused widespread disruption to the production lines of car manufacturers. If auto suppliers failed because of lost demand from a Chrysler liquidation, it could easily disrupt the other producers in the U.S., both in Detroit and in the transplants. Ford itself was arguing, publicly, for their competitors GM and Chrysler to receive bailouts on the grounds that their failure would endanger Ford's own production. We feared a chain reaction.

As the academic legal debate over bankruptcy law has observed, bankruptcy is largely a micro solution, aimed at reorganizing the assets and liabilities of a single firm (see Warren, 1987; Baird, 1987). It is not a macro solution. It does not take cross-industry spillovers or broader government or social costs into account. The auto taskforce attempted to quantify and weigh many of these factors in a reasonable way, though there was much disagreement on the details and magnitudes. For example, our estimates of job losses and supplier impacts often came from the industry's own representatives who had an incentive to exaggerate their estimates. One of our roles, for example, was to note that about half of the employees in the auto supply chain were involved in manufacturing replacement parts, which still would have been in demand even with a failure of domestic automakers. 


\section{The Decision and the Aftermath}

President Obama heard the analysis on all sides of the issue. He concluded that the economy should not risk the failure of both companies in 2009 and opted to rescue both GM and Chrysler. Rattner (2010, p. 120) notes, “The case for saving Chrysler was based more on political and social reality.” President Obama made the decision to reject the viability plans the companies submitted from the first round of loans and ordered a new and more serious restructuring effort, led by the team of private sector turnaround experts that he brought into the administration. Separate from the efforts made to reorganize the car manufacturers, the rescue effort also included providing money to the affiliated finance companies and auto suppliers, and guaranteeing of warranties to customers. ${ }^{1}$

In an industry with high fixed costs, annual profitability is largely determined by total market demand - known in the auto trade as the Seasonally Adjusted Annual Rate (SAAR) of lightweight vehicle sales—along with market share and price. Price depends on perceived quality and resale value. We examine developments in costs, product quality, prices, market share and SAAR below.

\section{Massive Restructuring and Cost Reduction}

We knew that a lasting restructuring of Chrysler and GM would likely require a number of steps: reducing their legacy costs to bondholders and retirees, reducing their number of dealers, cutting capacity and weaker brands, and expanding a two-tier structure where newly hired workers were paid less than incumbents. In March 2009 President Obama instructed his auto team, "I want you to be tough and I want you to be commercial," in regards to setting terms for

\footnotetext{
${ }^{1}$ A clever market-based mechanism was used to extend credit to critical suppliers by giving automakers access to funds to use to keep their critical suppliers afloat. However, only $\$ 413$ million of $\$ 5$ billion allocated to this program was lent to suppliers; all of it was eventually repaid to Treasury.
} 
an alliance between Chrysler and Fiat and restructuring GM (Rattner, 2010, p. 132). The funds that the U.S. Treasury provided to Chrysler and GM came with strict requirements on their restructuring. Because of their different financial positions, most of the support provided to GM took the form of equity, while support for Chrysler was in the form of debt that needed to be repaid. One could justify the less generous terms of support for Chrysler in part because Chrysler was in more precarious financial shape than GM in 2009, and in part because Chrysler was less pivotal for the near-term course of the auto industry and economy given its smaller size.

As a condition of the earlier government loans, GM agreed to cut its debt by $\$ 30$ billion by converting debt into equity. It also agreed to cut employment from 96,000 to 45,000 by 2012, bring its labor costs in line with the transplants' by 2012, sell its Saab, Saturn and Hummer divisions, and reduce its number of models from 45 to 40 . GM failed to meet the full conditions of the bailout, and its CEO, Rick Wagoner, was replaced in March 2009. On June 1, 2009, GM filed for bankruptcy with $\$ 173$ billion in liabilities and $\$ 82$ billion in assets. The company closed a dozen plants and eliminated more than 20,000 jobs. Stockholders were wiped out and bondholders were issued new stock worth much less than the value of their bonds. More than 1,100 of 6,100 dealerships would eventually close. GM emerged from bankruptcy quickly, on July 10, 2009, as two separate companies. About half of the members of the board of directors were replaced, and several top executives were dismissed or reassigned. The old company retained the liabilities, and a "Shiny New GM" held the assets and soon became profitable, earning its first annual profit in ten years in 2010. Retiree health benefits, funded by an entity known as a voluntary beneficiary benefits association (VEBA), were cut for GM's more than 330,000 retirees and surviving spouses in the U.S., and the VEBA was funded primarily with an equity stake in the company. 
Chrysler filed for bankruptcy on April 30, 2009. The company closed 789 of its 3,200 dealerships as part of its bankruptcy reorganization. More than a dozen plants closed. Under agreement with the UAW, the two-tier wage system was expanded, with wages for new hires cut to about half of the $\$ 29$ per hour that longtime union members earned, although they were raised to $\$ 17$ an hour in 2011. Defined benefit pensions were eliminated for new hires and replaced with 401(k) plans. Overall wage and benefit costs at Chrysler and GM were brought down to be roughly in line with those at Honda and Toyota plants operating in the U.S. Benefits provided by Chrysler's voluntary beneficiary benefits association (VEBA) were also slashed, and the VEBA received a 55 percent equity stake in the company. Fiat gained minority ownership and corporate control of the restructured Chrysler.

Restructuring the two failing auto companies reduced their fixed and variable costs at the expense of much pain for their creditors, workers, managers, and dealers. ${ }^{2}$ Just as importantly for their long-run success, the new management of the companies sought to improve the culture of their organizations and introduce better business practices to produce higher quality cars. From brakes, wheels and suspension to styling and advertising - including popular commercials featuring Eminem and Clint Eastwood launched during the 2011 and 2012 Super Bowls - an attempt was made to improve the culture and quality of work at Chrysler, in particular. Chrysler posted a profit in the first quarter of 2010. When asked what had changed at Chrysler, Fiat CEO Sergio Marchionne (2014) recently responded: “The culture; the technology that's in place; the way in which the cars are manufactured; the attitude of the workforce; the efficiency; the land speeds; the output of the system has completely changed. I mean, if you took a Japanese guy

\footnotetext{
${ }^{2}$ Anticipating that restructuring the companies would cause much pain and disruption, we recommended that the President establish a Director of Recovery for Auto Communities and Workers to coordinate agencies and resources across the federal government to ease the transition for hard hit communities and workers. Economist Edward Montgomery, now at Georgetown University, ably served in this capacity.
} 
into our plant today he'd be impressed.” Marchionne offered a simple explanation for why Chrysler was able to change so quickly: "I know that when you're broke you change your ways a lot faster.”

\section{Price Discounts and Perceived Quality}

In the longer term, we knew that for the auto companies to survive they needed also to deal with the falling demand for their products. Prior to the financial crisis, Chrysler and GM concentrated on producing larger, less fuel efficient, and more costly to produce models than their competitors, and offered aggressive price discounts to consumers.

Since the restructuring, there are some signs that quality has improved and that price discounting has become less aggressive, though the jury is still out. Figure 2 reports the JD Power quality rating for Chrysler, and GM, and Ford and for all other automakers combined. JD Power's Initial Quality Study provides information on new-vehicle quality based on a survey of a nationally representative sample of car buyers (results weighted to reflect sales). The questionnaire asks car owners to indicate which, if any, problems they have experienced from a list of 228 possible items, and they can write in any additional problems not included on the list. Figure 2 reports the number of problems per 100 vehicles. A lower figure indicates fewer problems and higher quality. Although this measure is crude (e.g., some problems are worse than others), it is a common metric of quality in the industry.

In 2010 and earlier years, owners of new Chrysler and GM vehicles reported a higher incidence of problems than owners of other cars. Starting in 2011, however, this measure of quality improved considerably for Chrysler and GM, with the number of problems reported per new car about on par with that of the other auto manufacturers. 
More recently, however, in 2014 GM agreed to pay the Department of Transportation the maximum civil penalty of \$35 million for failing to report and delaying a recall of 2003-11 cars with defective ignition switches and airbags that failed to deploy, a problem that GM reportedly was aware of at least as early as November 2009. In total, GM recalled 29 million cars in North America as of the middle of 2014, breaking the record for most recalled cars in any full year and Chrysler has launched its own recalls for ignition switches. Although these recalls point to clear quality problems, the extent to which quality has improved since 2010 remains an open question.

Figure 2. JD Power's Initial Quality Survey (Problems Per 100 Vehicles)

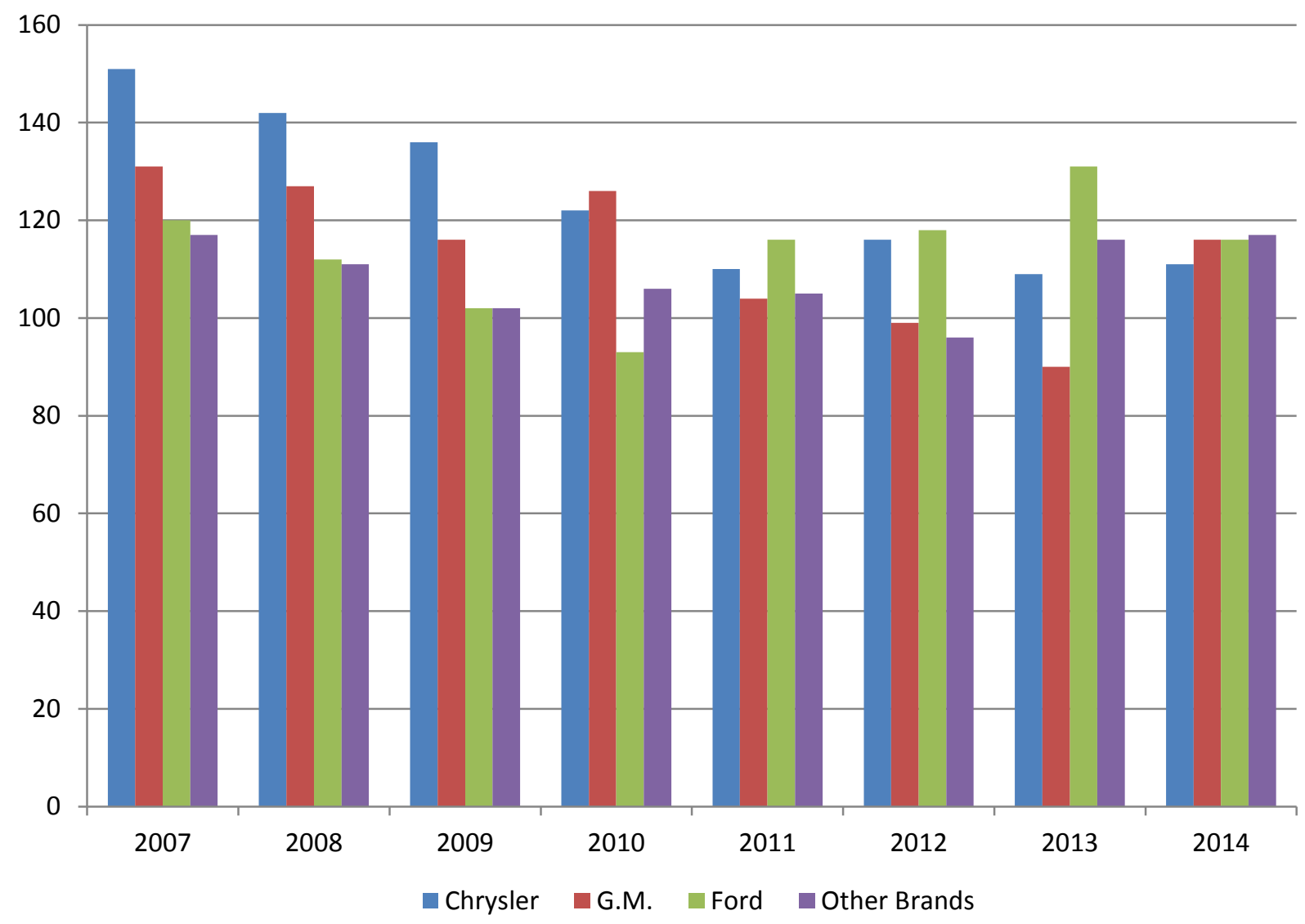


Data that allow price comparisons among cars are sketchy, but indicate that the Detroit brands continued to offer steeper discounts than other automakers after 2009; nonetheless, their discounts and incentives relative to the industry average fell by about 10 percent from 2002-08 to 2009-11. Chrysler’s CEO Sergio Marchionne, in particular, has waged a campaign against price discounting, emphasizing that, "Unprofitable volume is not volume I want," and reportedly berated Chrysler's head of sales, who was dismissed shortly afterwards, for seeking to offer price rebates along with Cash for Clunkers (Linebaugh and Bennett 2010). General Motors reduced its sales incentives below those of Chrysler and Ford by February 2014, but the company subsequently sharply increased discounts to counteract a drop in demand due to adverse publicity over the recalls in spring 2014 (Kessler and Vlasic 2014).

\section{Market Share}

The market share of each of the Big Three automakers was presented in Figure 1. As a benchmark, the graph also shows the trend projected from a linear regression over the period 1988-2008. General Motors market share has been on a downward trajectory for the past 50 years, falling from 50.7 percent of the market in 1962 to 40.4 percent in 1985, 30.6 percent in 1997, and 19.6 percent in 2009. Ford's market share has also trended down from 29 percent in 1961 to 14 percent in 2008, with a notable reversal in the period from1981 to 1995 , and then a sharper decline through 2008. Chrysler’s market share, by contrast, fluctuated between 10 and 15 percent from 1961 to 2008, and fell to an all-time low of 8.8 percent in 2009.

After 2009, Chrysler's share of the market rose for five consecutive years, its best performance since the early 1990s. Chrysler's market share stood at 12.3 percent in the first half of 2014, 3.5 percentage points, or 40 percent, above its 2009 level. These gains have been 
widely attributed to the improved management and higher quality product initiated by Sergio Marchionne. And the drop in gasoline pricesalso probably boosted the Big Three's market shares above what they otherwise would have been by raising demand for larger vehicles,.

One of our main concerns about the auto rescue was that the domestic brands, to a considerable degree, compete with each other, so rescuing Chrysler, the weakest and smallest of the three firms, would make it harder (and more expensive for taxpayers) for General Motors to survive. There appears to be some support for this view, as GM's market share continued to decline after 2009, and its decline was at least as quick as it was over the preceding two decades. The fact that GM eliminated four unprofitable brands—-Saturn, Pontiac, Hummer and Saabalso undoubtedly contributed to its decline in market share after 2009.

It is impossible to know what would have happened to market shares of GM had Chrysler been liquidated in 2009, but the data in Figure 1 show a notably strong rebound in Chrysler’s market share, from a historically low base, and a continuation of GM's decades' long decline. The market share of the Big Three combined stood at 45.1 percent in the first half of 2009, above their 2009 combined low of 43.7 percent in 2009, but well below their share of 50.5 percent on the eve of the economic crisis in 2007. These figures suggest that, to some extent, Chrysler's gains came at the expense of the other domestic firms.

\section{Rebound in Aggregate Auto Demand}

The biggest factor contributing to the positive recovery of the automakers, however, has been the rapid rebound of consumer demand for autos more generally. Auto sales are normally pro-cyclical. Figure 3 shows that nationwide sales plummeted during the Great Recession, falling to their lowest quarterly level since the deep 1981 recession. Many factors affect car 
sales, in addition to the state of the economy, such as population growth, credit availability and the age and durability of the existing fleet. We and many industry analysts expected sales to bounce back to around 15 to 15.5 million a year when the economy normalized. In its submission to the government in February 2009, GM's baseline forecast of annual sales was 16 million units in 2012 and market share was 20 percent. (GM was too optimistic: in 2012, actual sales were 14.4 million and GM’s market share was just 17.6 percent.)

Figure 3 shows auto sales each quarter since 1976. To compare actual sales to what one would predict from a forecasting model, we regressed quarterly sales of light weight vehicles (adjusted to the "seasonally adjusted annual rate" or SAAR) on real GDP growth, the unemployment rate, population growth, the Federal Reserve’s Senior Loan Officers’ Survey (SLOOS) measure of willingness to lend to consumers, the logarithm of the average real price of a gallon of gasoline in the previous quarter, and the standard deviation of gas prices over the preceding four quarters, using a sample from 1977:Q1 to 2007:Q4. (The sample begins in 1977 because gasoline price data from the Energy Information Administration are available starting in 1976.) The regression results are presented in Table 2, and Figure 3 shows the fitted values during the sample period and the projected values from 2008 forward. The explanatory variables account for 72 percent of the variability in quarterly car sales.

Most of the variables have their expected signs. For example, sales are stronger when the economy is stronger (i.e., faster GDP growth or lower unemployment) and when credit conditions are looser. Higher gas prices are associated with lower sales, although the relationship is weak and statistically insignificant. Greater variability in gas prices, however, is associated with higher sales, as households may adjust their model of car in response to recent movements in gas prices. 
Figure 3: Light Weight Vehicle Sales

Millions of Units (Seasonally Adjusted Annual Rate)

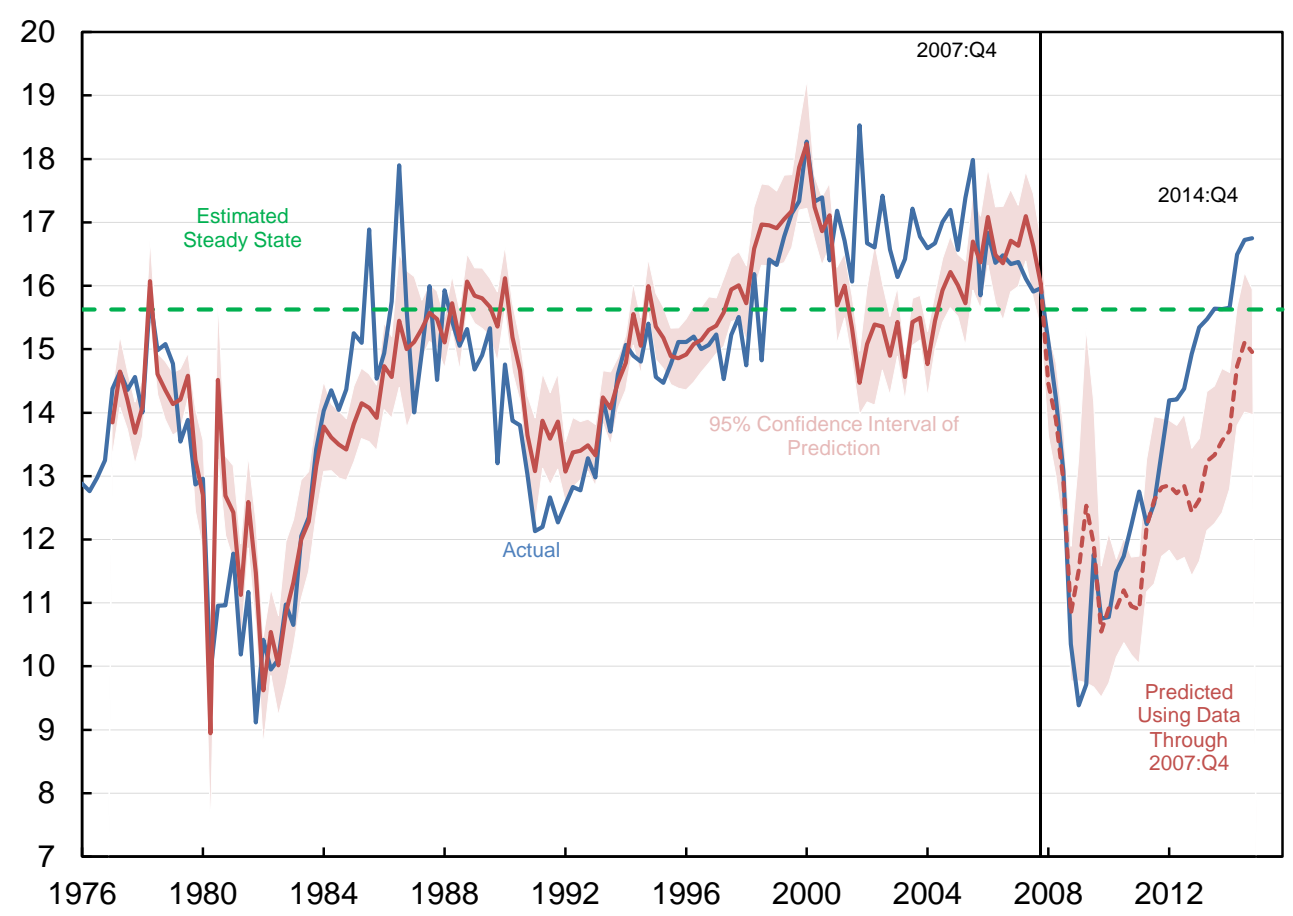

The model effectively captures the collapse in auto sales during the Great Recession, and predicts most of the rebound since the recession officially ended in mid-2009, although it under predicts actual sales in 2012-14. In the last quarter 2014, actual sales were 1.8 million above the level the model would predict at a seasonally adjusted annual rate. Part of the rebound in car sales appears to represent overshooting of actual sales relative to the prediction of the simple model. This pattern is not unexpected given the pent-up demand that accumulated during the Great Recession, and the fact that the parsimonious regression model used here ignores dynamics. There was some significant overshooting of sales early in two of the three previous recoveries as well. 
Table 2. Regression Model to Predict Light Weight Vehicle SAAR, 1977-2007

\begin{tabular}{|c|c|c|}
\hline & $\begin{array}{l}\text { Mean } \\
\text { (S.D.) }\end{array}$ & $\begin{array}{r}\text { Coefficient } \\
\text { (Std. Error) }\end{array}$ \\
\hline Real GDP Growth (\%) & $\begin{array}{r}3.20 \\
(3.10)\end{array}$ & $\begin{array}{r}0.099 \\
(0.025)\end{array}$ \\
\hline Unemployment Rate (\%) & $\begin{array}{r}6.12 \\
(1.41)\end{array}$ & $\begin{array}{r}-1.150 \\
(0.093)\end{array}$ \\
\hline Population Growth (\%) & $\begin{array}{r}1.28 \\
(0.58)\end{array}$ & $\begin{array}{r}0.226 \\
(0.116)\end{array}$ \\
\hline SLOOS Credit Availability & $\begin{array}{r}109.24 \\
(16.57)\end{array}$ & $\begin{array}{r}0.044 \\
(0.009)\end{array}$ \\
\hline Log Gasoline Price (lagged) & $\begin{array}{r}0.63 \\
(0.24)\end{array}$ & $\begin{array}{r}-0.027 \\
(0.808)\end{array}$ \\
\hline $\begin{array}{l}\text { Standard Dev. of Log Gasoline Price } \\
\text { over Previous Four Quarters }\end{array}$ & $\begin{array}{r}0.056 \\
(0.036)\end{array}$ & $\begin{array}{r}8.657 \\
(4.033)\end{array}$ \\
\hline Constant & --- & $\begin{array}{r}15.948 \\
(1.357)\end{array}$ \\
\hline R-Square & & 0.716 \\
\hline
\end{tabular}

Notes: Mean (S.D.) of dependent variable is 14.8 million (2.0 million) SAAR.

Newey-West standard errors with four lags in parentheses. Sample consists of 124 quarterly observations from 1977:Q1 to 2007:Q4. Real GDP Growth, Unemployment Rate and Population Growth are seasonally adjusted and at an annual rate. The log of the real price of gasoline is for the previous quarter, and gas prices were deflated by the Personal Consumption Expenditures deflator. The standard deviation of log real gas prices is over the preceding four quarters.

In early 2009, the widely respected economic forecasting firm Macroeconomic Advisers, which had expected a strong economic recovery (GDP growth of 3.9 percent and unemployment rate of 5.8 percent in 2013), predicted that auto sales would reach 15.4 million in 2013. The fact 
that auto sales slightly exceeded that amount at 15.5 million, despite their overly optimistic assumptions about the state of the economy, is a sign that the rebound in auto sales exceeded expectations given the actual path of the recovery.

To gauge the importance of the rebound in sales for the fate of the auto rescue, suppose that domestic auto sales had remained at 9.5 million instead of rebounding to 16.5 million in 2014:Q2. In this scenario Chrysler would have needed to raise its market share by 12.4 percentage points to achieve the actual volume of sales it registered in 2014:Q2. Thus, Chrysler's impressive 3.5 percentage point gain in market share was far less significant than the overall rebound in market demand.

We can use the coefficients from the regression model in Table 2 to derive an estimate of "steady state" car sales. Specifically, we assumed the values of the explanatory variables would equal the forecast of real GDP growth and unemployment used by the Obama administration for the "out year" forecasts in 2023, which are best-understood as an estimate of long-run underlying trends. Specifically, we assume a 2.3 percent rate of GDP growth and an unemployment rate of 5.4 percent, correspond to the 2023 forecasts in the administration's FY2015 Budget (Table 2-1). We assume a growth rate for the in the civilian non-institutional population of 0.9 percent, corresponding to the 2023 baseline forecast in CBO’s February 2014 “Budget and Economic Outlook.” For the SLOOS credit availability variable, log of real gas prices, and standard deviation of log gas prices, we use the average values over the period 2002:Q1 to 2007:Q4. This calculation suggests that steady state annual car sales will be around 15.6 million.

If our estimate of steady state car sales is correct, sales may slip by about 7 percent from their current level. For Chrysler, this amounts to about a quarter of their post-restructuring gain in market share. Given the restructuring of costs, we suspect that there will be sufficient demand 
to sustain the Big Three at their current level of market share. In addition, there is room for GM potentially to raise its profitability by implementing some of the tough measures that Chrysler has implemented. But steady state market demand is probably just large enough to sustain the existing domestic firms, and there is little margin for the companies to be viable ongoing concerns if they are mismanaged in the future.

\section{Autos and Industrial Recovery}

Even in the information age, the auto industry remains a major contributor to the U.S. economy. Moreover, modern automobiles are advanced manufacturing products. We were told by Ford, for example, that the value of electronics, software and intellectual property accounts for about 30 percent of the average vehicle’s price.

Manufacturing played a critical role in the recovery from the Great Recession, and autos played an outsized role in the manufacturing recovery. Five years after the start of the recovery, the rise in motor vehicles and parts production accounted for more than 25 percent of the rise in total manufacturing industrial production, even though motor vehicles and parts account for only about 6 percent of total manufacturing value added. Although it is not unusual for the auto industry to punch above its weight early in a recovery, it has played an unusually large role relatively long into the current recovery. At the same point in the last four recoveries, motor vehicles and parts accounted for only 11 percent of the rise in manufacturing production, on average.

Since bottoming at 623,300 jobs at the trough of the recession in June 2009, employment in the motor vehicles and parts manufacturing industry has increased by 256,000 jobs (as of July 2014). This is a stark contrast from the previous recovery, when jobs in the industry steadily 
declined. The increase in the number of jobs in motor vehicles and parts manufacturing accounted for nearly 60 percent of the total rise in manufacturing jobs in the recovery's first five years. In addition, some 225,000 jobs have been added at motor vehicle and parts dealers. Counting both manufacturers and dealers, auto-related jobs accounted for 6 percent of the total 8.1 million jobs that were added, on net, in the first five years of the recovery -- triple the sector's 2-percent share of total employment. Although the auto sector played an outsized role in the recovery, it should also be apparent that given the relatively low share of employment in autos and related jobs, there is a limit to how much the auto rebound could have driven the jobs recovery.

\section{Exit Strategy}

The U.S. Treasury Department provided roughly $\$ 80$ billion in assistance to the auto industry: $\$ 51$ billion to GM, $\$ 12.5$ billion to Chrysler, and $\$ 17.2$ billion to what is now Ally Financial, but was formerly GMAC Finance (see www.treasury.gov/initiatives/financialstability/TARP-Programs/automotive-programs/Pages/default.aspx). By the end of 2014, the government had closed all three of these positions.

At Larry Summers’ direction, the Obama administration established principles for its role as majority owner of GM. These included: setting upfront business goals and selecting executives and a strong board of directors; only voting as a shareholder on major corporate governance issues or major transactions; letting the board and management run the company; selling the government's shares as soon as practicable to recover taxpayer money and return the company to private ownership. A similar approach was taken to Chrysler. From the outset, we were determined to avoid the problem that had worsened Japan's stagnation in the 1990s and 
2000s of propping up 'zombie' companies for long periods of time that should have ceased to exist. As President Obama put it, his goal was, "To get GM back on its feet, take a hands-off approach and get out quickly.”

On December 9, 2013 - much sooner than virtually anyone expected -- the government fully exited its investment in GM by selling its remaining shares, and critics could no longer say that GM stood for Government Motors. Treasury recovered a total of $\$ 39.7$ billion from its investment of $\$ 51.0$ billion in GM. By the end of 2014, Treasury sold its remaining stake in Ally Financial, recovering $\$ 19.6$ billion from the original $\$ 17.2$ billion investment in Ally, for a $\$ 2.4$ billion gain for taxpayers.

In May 2011, Chrysler repaid its outstanding TARP loans six years ahead of schedule. Chrysler returned $\$ 11.2$ billion of the $\$ 12.5$ billion it received through principal repayments, interest, and cancelled commitments, and the Treasury fully exited its connection with Chrysler. In January 2014, Fiat purchased the shares in Chrysler owned by the VEBA and took full ownership of Chrysler.

For the most part the administration adhered to its goals and avoided political meddling. There were some notable exceptions, however. For example, when GM’s Chief Executive wanted to move the company's headquarters from the Renaissance Center in Detroit to its Tech Center in Warren, MI to be closer to the workforce, which made some business sense, the administration blocked the move. Congress and the administration both set restrictions on executive compensation for TARP recipients (for example, the CEO's annual compensation was capped \$9.5 million). The administration included a "vitality commitment" as a condition of receiving funding, which prevented the companies from moving work at U.S. plants to other 
countries. And members of Congress frequently attempted to intervene to prevent unnecessary and inefficient dealerships from being closed, to the administration's consternation.

Some have argued that the rescue improperly paid unsecured union workers ahead of unsecured bondholders due to political pressures. The wider debate about the bankruptcy law and the rescue is beyond our scope but we have a few observations. First, as a legal matter, a large majority of bondholders voted for the deal and a bankruptcy judge approved it. That is why it proceeded. This was not something the administration unilaterally decided. Second, there were legitimate business reasons why one might need to pay some unsecured creditors so the firms would be able to continue operating. Guaranteeing the warrantees of car owners, for example, also prioritized unsecured creditors. But if consumers did not trust the warranties, demand for cars likely would drop precipitously. Likewise, if workers refused to accept the deal or shirked on their duties, the auto makers' viability as an ongoing concern was in jeopardy. Similar payments were made to workers in the bankruptcies of the steel companies in the 1980s, where there was not a government rescue. Third, despite their haircut, bondholders almost certainly received well more than they would have under the alternative had the government not intervened in the depths of the crisis. And despite insinuations to the contrary, incumbent workers took dramatic cuts to their benefits and bore substantial risk in the VEBA.

\section{Conclusion}

Economists and economic analysis had a key seat at the table in the decision to rescue and restructure GM and Chrysler. The decision was risky. Those of us involved gathered all the information we could find and tried to put, finally, the companies on a sustainable footing. We did not know if it would work. In particular, we had reservations about the long-run viability of 
the Chrysler-Fiat merger. In an interview in the Detroit News (Shepard 2015), President Obama explained his decision this way: "There was clear-eyed recognition that we couldn't sustain business as usual. That's what made this successful. If it had been just about putting more money in without restructuring these companies, we would have seen perhaps some of the bleeding slowed but we wouldn't have cured the patient.

To their credit, the companies restructured to a greater degree than they had ever done before and under extreme pressure, and - after shedding much legacy debt -- returned to profitability in 2010. They also were fortunate that the economy began to turn around and that consumer demand for autos rebounded strongly.

It is fair to say that no one involved in the decision to rescue and restructure GM and Chrysler ever wanted to be in the position of bailing out failed companies or having the government own a majority stake in a major private company. We are both thrilled and relieved with the result: the automakers got back on their feet, which helped the recovery of the U.S. economy. Indeed, the auto industry's outsized contribution to the economic recovery has been one of the unexpected consequences of the government intervention. The automakers' future success will depend on their own managerial decisions in the years to come. The fact that Ford was able to weather the economic downturn and financial crisis because it had taken precautionary steps and efforts to restructure before calamity hit, while GM and Chrysler could not have survived without extraordinary government support, is a stark reminder of the importance of good managerial decisions for the survival of businesses. 


\section{References}

Baird, Douglas (1987), "Loss Distribution, Forum Shopping, and Bankruptcy: A Reply to Warren," 54 University of Chicago Law Review 815.

Cole, David, et al. (2008), "CAR Research Memorandum: The Impact on the U.S. Economy of a Major Contraction of the Big Three Automakers,” Center for Automotive Research, Nov. 4, 2008.

Congressional Oversight Panel, "The Use of TARP Funds in the Support and Reorganization of the Domestic Automotive Industry,” September 2009. www.gpo.gov/fdsys/pkg/CHRG111shrg51964/html/CHRG-111shrg51964.htm

Helper, Susan (2010), "Parts: Managing the Supply Chain", presentation at the Chicago Fed conference "After the Perfect Storm: What's Next for the Auto Industry", May 10th. www.chicagofed.org/digital_assets/others/events/2010/automotive_perfect_storm/helper.pdf

Kessler, Aaron and Bill Vlasic, “To Lift Sales, G.M. Turns to Discounts,” New York Times, July 31, 2014.

Kiley, David (2009), "Billions for Auto Suppliers' Bailout" BusinessWeek, March 19.

Kurylko, Diana (2013), "Transplants Keep Rolling in North America," Automotive News, April 22.

Leonhart, David (2015), “\$73 an Hour: Adding It Up,” The New York Times, December 9, 2008. www.nytimes.com/2008/12/10/business/economy/10leonhardt.html?_r=4\&em\&

Linebaugh, Kate and Jeff Bennett, "Marchionne Upends Chrysler's Ways: CEO Decries Detroit's 'Fanatical' Focus on Market Share; Deep Discounts Are Out,” Wall Street Journal, Jan. 12, 2010.

Marchionne, Sergio (2014). Transcript. Brookings Institution. www.brookings.edu/events/ 2014/05/21-assessment-of-auto-bailout-us-manufacturing\#/full-event/.

Montopoli, Brian. 2009. “Obama: We Don’t Want to Run GM.” CBS NEWS, June www.cbsnews.com/news/obama-we-dont-want-to-run-gm.

Motor \& Equipment Manufacturers Association, Motor Vehicle Supplier Sector Emergency Financial Assistance Request, Submitted to U.S. Department of Treasury, February 13, 2009.

Nardelli, Robert (2008), Testimony, Committee on Financial Services, U.S. Senate "Stabilizing the Financial Condition of the American Automobile Industry", 110th Congress, Second Session, November 19, 2008. Serial No. 110-146

<http://www.gpo.gov/fdsys/pkg/CHRG-110hhrg46594/html/CHRG-110hhrg46594.htm> 
Rattner, Steven (2010), Overhaul: An Insider's Account of the Obama Administration's Emergency Rescue of the Auto Industry, New York, NY: Houghton Mifflin Harcourt.

Scott, Robert (2008), “When Giants Fall: Shutdown of one or more U.S. automakers could eliminate up to 3.3 million U.S. jobs,” EPI Briefing Paper, Dec. 3, 2008.

Shepard, David (2015), “Obama heralds U.S. auto turnaround,” The Detroit News, January 7, 2015, www.detroitnews.com/story/business/autos/2015/01/06/obama-autoturnaround/21367431/.

Stole, John and Jeffrey McCracken (2009), "Bankruptcy Fears Grip Auto-Parts Suppliers" Wall Street Journal, January 26, 2009.

Warren, Elizabeth (1987), "Bankruptcy Policy," 54 University of Chicago Law Review 775

Zandi, Mark (2008) Testimony before the U.S. Senate Banking Committee, "The State of the Domestic Auto Industry: Part II,” Dec. 4. 